\title{
Correction to: The First Measurement for Mass Attenuation Coefficients, Effective Atomic Numbers, and Electron Densities of Y123 and Y358 High-Temperature Superconductors (HTS) for the Energies from 46.6 to $1332 \mathrm{keV}$
}

\author{
İbrahim Düzgün ${ }^{1}$ (1)
}

Published online: 26 January 2022

(c) Springer Science+Business Media, LLC, part of Springer Nature 2022

Correction to: Journal of Superconductivity and Novel Magnetism (2021) 34:695-703

https://doi.org/10.1007/s10948-020-05771-0

The original version of this article contained a mistake. Thus this erratum is presented to fix this error. The section "Funding" should read as follows:

This study was funded by the Grant-in-Aid for Gümüşhane University Research Fund (GÜBAP), from the Gümüşhane University (Project Number: 13.F5120.02.1).

Publisher's Note Springer Nature remains neutral with regard to jurisdictional claims in published maps and institutional affiliations.

The original article can be found online at https://doi.org/10.1007/ s10948-020-05771-0.

İbrahim Düzgün

ibrahimduzgun@gumushane.edu.tr

1 Gümüşhane University, Physics Engineering, Gümüşhane,

Turkey 